\title{
Schistogram changes after administration of antischistosomal drugs in mice at the early phase of Schistosoma mansoni infection
}

\author{
Andréa Cássia Simões Vimieiro', Neusa Araújo² ${ }^{2}{ }^{1}$, Naftale $\mathrm{Katz}^{2,3}$, \\ John Robert Kusel ${ }^{4}$, Paulo Marcos Zech Coelho²
}

\begin{abstract}
${ }^{1}$ Hospital Alberto Cavalcanti, Fundação Hospitalar do Estado de Minas Gerais, Belo Horizonte, MG, Brasi ${ }^{2}$ Laboratório de Esquistossomose, Centro de Pesquisas René Rachou-Fiocruz, Belo Horizonte, MG, Brasil

${ }^{3}$ Academia Mineira de Medicina, Belo Horizonte, MG, Brasil ${ }^{4}$ University of Glasgow, Scotland, UK
\end{abstract}

Mice infected with Schistosoma mansoni were treated with oxamniquine, praziquantel, artesunate at the pre-patent phase, aiming at observing schistogram alterations. Half of the animals were perfused five days post-treatment for counting and classification of immature worms, based on pre-established morphological criteria (schistogram); the remaining animals were evaluated 42 or 100 days after infection and perfusion of the portal-system was performed for collection and counting of adult worms and oogram. It was observed that oxamniquine and artesunate treatment administered at the pre-postural phase causes significant reduction in the number of immature and adult worms. However, there was little reduction with praziquantel when used at the dose of $400 \mathrm{mg} / \mathrm{kg}$ for treatments administered 14, 15, 21 or 23 days post-infection. Artesunate was responsible for significant alterations in development of young worms, as well as for a higher number of worms presenting intestinal damages. Immature adult worms were detected in mice treated with artesunate or oxamniquine at the pre-patent phase of infection and recovered by perfusion 100 days after infection. Schistogram proved to be a very useful tool for experimental evaluation of the activity of antischistosomal drugs and a good model to identify the most sensitive stages to drugs.

Key words: schistogram - Schistosoma mansoni - oxamniquine - praziquantel - artesunate - oogram

One of the major challenges of schistosomiasis chemotherapy is the efficacy of treatment at the initial phase of the disease. It is well known that Schistosoma mansoni development from the schistosomulum stage to the adult worm is accomplished through evolutive stages, with morphological changes and a large body growth. Faust et al. (1934) using experimental infection in rats, rabbits and monkeys observed that this development occurs in an asynchronous way.

Several authors have already demonstrated that at the initial stage of development (immature worms) S. mansoni is less susceptible to chemotherapeutic action, including oxamniquine and praziquantel (Xiao et al. 1985, Sabah et al. 1986, Silva et al. 2003, Pica-Mattoccia \& Cioli 2004, Botros et al. 2005, Grandière-Pérez et al. 2006).

Sabah et al. (1986) demonstrated that $S$. mansoni immature worm is less susceptible at least to six antischistosomal drugs: antimonium and potassium artesunate, hycanthone, oxamniquine, niridazol, amoscanato and praziquantel, used at doses considered curative against adult worms. The six tested drugs were ineffective against worms already housed in the portal system. It is noteworthy that hycanthone, oxamniquine, praziquantel and niridazol showed activity against schistosomula up

doi: 10.1590/0074-0276130135

Financial support: FIOCRUZ, CNPq

+Corresponding author: araujon@cpqrr.fiocruz.br

Received 17 May 2013

Accepted 12 June 2013 to two-week-old. It was observed that there was a greater activity against mature adult worms than in five-sixweek-old worms. An important result was the total or partial activity on two-five-week-old worms.

Treatment of infection at the initial stages would bring a great advantage for vertebrate hosts, since it would avoid production of eggs and, consequently, formation of granulomas, which are the fundamental elements of the pathology of the disease (Bogliolo 1959, Warren 1968, Enk et al. 2008, Coelho et al. 2009).

The fundamentals of the present study are based on the well established biological fact that immature worms, by reasons related to time required to reach the portalhepatic system, coming from the lungs, present a marked evolutive asynchronism (Faust et al. 1934, Barbosa et al. 1978). This fact could explain, at least in part, the difficulty of conventional antischistosomal drugs, administered at the initial phase of infection, to eliminate with efficacy all the parasites, considering the difference of susceptibility to the drug regarding the mentioned stage of worm development.

The procedure related to counting of schistosomula recovered by perfusion of animals previously infected with $S$. mansoni cercariae and their classification based on morphological criteria (1st-6th stages), according to intestinal development generating the percentage related to each evolutive stage in the portal system, is called schistogram (Barbosa et al. 1978).

This study evaluated the activity of oxamniquine, praziquantel and artesunate, administered alone or in association, in the initial phases of infection using schistogram as a parameter, trying to identify the developmental stages that are most vulnerable or resistant to drug action. 
For treatment three antischistosomal drugs, which are currently used for schistosomiasis treatment, were selected oxamniquine, praziquantel and artesunate, administered alone or in association (Utzinger et al. 2002, Lu et al. 2004, Shaohong et al. 2006).

\section{MATERIALS AND METHODS}

Infection of mice - Swiss female mice, weighing approximately $20 \mathrm{~g}$, infected with $200 \pm 10 \mathrm{~S}$. mansoni cercariae (LE strain), by subcutaneous route, or 50 cercariae when mice were sacrificed 100 days after infection, were used in this study.

Treatment of animals - Oxamniquine, praziquantel and artesunate were administered in monotherapy or in association (praziquantel and artesunate), always with single dose and by oral route. The schedules utilised for treatments were as follows: oxamniquine $-200 \mathrm{mg} / \mathrm{kg}$ or 400 $\mathrm{mg} / \mathrm{kg}$ weight in monotherapy, praziquantel - $400 \mathrm{mg} / \mathrm{kg}$ or $800 \mathrm{mg} / \mathrm{kg}$ in monotherapy or in association with 300 $\mathrm{mg} / \mathrm{kg}$ or $600 \mathrm{mg} / \mathrm{kg}$ artesunate, which was also used in monotherapy with the same doses as the association.

The animals were treated 14, 15, 21 or 23 days postinfection and the perfusion of mice was performed five, 42 or 100 days after treatment for collection, counting and classification of worms.

Evaluation of schistosomicidal activity - In order to evaluate the activity of drugs at the pre-patent (pre-postural) phase of infection, the animals were submitted to euthanasia by cervical fracture (experimental groups and controls in all the schedules). After that, the animals were submitted to perfusion of the mesenteric veins and liver, according to the technique prescribed by Pellegrino and Siqueira (1956) for worm recovery. After perfusion of the portal system, the recovered immature worms were counted and classified using a stereomicroscope. Morphological criteria, based on the development of the digestive tract of the parasite after ingestion of blood, were used for its classification regarding its evolutive stage, constituting the schistogram (Barbosa et al. 1978).

For activity evaluation at the patent phase, perfusion of mesenteric veins and liver was performed aiming at recovering and counting adult worms (Pellegrino $\&$ Siqueira 1956). The livers were crushed between slide and coverslip and observed under a stereomicroscope for counting of dead worms; fragments from the distal portion of the small intestine, measuring approximately $1 \mathrm{~cm}$, were compressed between two plastic slides and observed under optical microscope for detection of $S$. mansoni eggs at different evolutive stages (Pellegrino et al. 1962).

Groups of untreated infected mice (control of infection) were kept in all the schedules and were submitted to the same procedure for treated animals, except treatment.

Schistogram changes were observed taking into account differences in the average of recovered immature worms, at each evolutive stage after comparison to untreated control and percentage in reduction of recovered adult worms of treated groups in relation to untreated control.
The average of recovered worms, distribution of worms in the liver and mesentery, percentage of dead worms in the liver and of oogram changes were indicators of drug activity on the adult worm (Pellegrino \& Katz 1968).

Statistical analyses - All the results were submitted to normality test. Kruskal-Wallis test, followed by Dunn's multiple comparison, were applied to non-parametric data, whereas Pearson's $\mathrm{X}^{2}$ test and ANOVA, followed by Tukey's multiple comparisons, were applied to parametric data.

Ethics - The guidelines of the Ethical Committee for the use of experimental animals of Oswaldo Cruz Foundation were followed (CEUA L-018/09).

\section{RESULTS}

The results obtained in all the experiments are presented in Tables I-IV.

Except for praziquantel, administered at the dose of $400 \mathrm{mg} / \mathrm{kg}, 15$ or 23 days post-infection, it was observed a significant decrease in the mean number of worms recovered by perfusion in all the other therapeutic schedules used. Oxamniquine reduced from 70.2-57\% the young worms at fourth evolutive stage, when treatment was administered 15 days after infection and it was observed a statistically significant increase in the percentage of worms (4th evolutive stage) when the drug was used 23 days after infection; the drug also reduced 70\% of the worms at the sixth evolutive stage and increased from $1 \%$ (control group) to $13.3 \%$ (oxamniquine $400 \mathrm{mg}$ / $\mathrm{kg}$ ) the percentage of unidentified worms due to intestinal damages (NI), when treatment was administered 23 days post-infection. Treatment with artesunate was responsible for a significant decrease in the percentage of young worms at third stage $(300 \mathrm{mg} / \mathrm{kg}$, treatment on 15 days after infection), as well as an increase in the percentage of worms at second stage; there was also a decrease about $30 \%$ and $50 \%$ in the percentage of worms at third and fourth stages, respectively (dose of $600 \mathrm{mg} / \mathrm{kg}$, treatment 15 days after infection) and diminished by almost half the percentage of worms at fourth, fifth and sixth evolutive stages (dose of $600 \mathrm{mg} / \mathrm{kg}$, treatment 23 days after infection). The percentage of immature worms, which could not be assigned to any of the six stages and were considered as NI, was at most $4 \%$ in untreated mice. On the other hand, a significant increase in the percentage of NI could be observed, varying from $16.9 \%$ (animals treated 15 days post-infection with $300 \mathrm{mg} / \mathrm{kg}$ artesunate) to $38.8 \%$, when artesunate $(600 \mathrm{mg} / \mathrm{kg})$ was administered 23 days after infection. In relation to the other two drugs, only oxamniquine $(400 \mathrm{mg} / \mathrm{kg}$, treatment 23 days after infection) showed a significant increase in the percentage of NI $(13 \%, \mathrm{p} \leq 0.05)$ (Table I).

In all the schedules using different doses of oxamniquine, artesunate and praziquantel, 15 or 23 days postinfection, activity evaluation performed 42 days after infection showed a significant reduction in the mean of recovered worms, varying from $25.7 \%$ (when $200 \mathrm{mg}$ / $\mathrm{kg}$ oxamniquine or $400 \mathrm{mg} / \mathrm{kg}$ praziquantel were used) to $75 \%$ when treatment with $400 \mathrm{mg} / \mathrm{kg}$ oxaminiquine was administered 23 days after infection. The animals 


\section{TABLE I}

Distribution of young worms recovered from mice infected with 200 Schistosoma mansoni cercariae treated with single dose by oral route as monotherapy and submitted to euthanasia (treated and control groups) five days after treatment

Animals

(n)

Distribution of schistosomules per evolutive stage $(\%)$

\begin{tabular}{|c|c|c|c|c|c|c|c|c|c|c|c|}
\hline $\begin{array}{l}\text { Treatment schedule } \\
(\mathrm{mg} / \mathrm{kg})\end{array}$ & $\begin{array}{l}\text { Treated after } \\
\text { infection } \\
\text { (days) }\end{array}$ & Treated & Examined & $\begin{array}{l}\text { Mean of worm } \\
\text { (\% reduction) }\end{array}$ & 1 & 2 & 3 & 4 & 5 & 6 & NI \\
\hline Oxamniquine 200 & 15 & 13 & 13 & $12.5(57)^{a}$ & 0.5 & 12.2 & 36.8 & 50 & 0 & 0 & 0.5 \\
\hline Artesunate 300 & 15 & 13 & 13 & $10.0(65.6)^{a}$ & 3.8 & 8.5 & $10.8^{b}$ & 57.7 & 2.3 & 0 & $16.9^{b}$ \\
\hline Praziquantel 400 & 15 & 13 & 13 & $16.5(43.3)^{a}$ & 0.9 & 6 & 24.2 & 67.5 & 0.9 & 0 & 0.5 \\
\hline Control & - & - & 12 & $29.1(0)$ & 3.1 & 7.2 & 26.4 & 59 & 0.3 & 0 & 4 \\
\hline Oxamniquine 200 & 23 & 13 & 12 & $37.0(31.2)$ & 0 & 0 & 0.7 & 14.6 & 37.8 & 46.8 & 0 \\
\hline Artesunate 300 & 23 & 13 & 13 & $27.8(48.3)^{a}$ & 0 & 0.3 & 0.3 & 13 & 31.6 & 54.8 & 0 \\
\hline Praziquantel 400 & 23 & 13 & 13 & $42.7(20.6)$ & 0 & 0 & 2 & 13.5 & 38.3 & 46.2 & 0 \\
\hline Control & - & - & 11 & $53.8(0)$ & 0 & 0.3 & 1.2 & 8.9 & 32.9 & 56.7 & 0 \\
\hline Oxamniquine 400 & 15 & 13 & 9 & $33.3(43.7)^{a}$ & 1.7 & 17 & 24.3 & $57^{a}$ & 0 & 0 & 6 \\
\hline Artesunate 600 & 15 & 13 & 12 & $24.1(59.2)^{a}$ & 6.2 & $19^{a}$ & $12.1^{a}$ & $35.6^{a}$ & 0 & 0 & $27^{b}$ \\
\hline Praziquantel 800 & 15 & 13 & 9 & $28.9(51.1)^{a}$ & 1.5 & 13.8 & 29.6 & $54.6^{a}$ & 0 & 0 & 0.4 \\
\hline Control & - & - & 11 & $49.4(16.4)$ & 0.9 & 7.4 & 18.8 & 70.2 & 0.6 & 0 & 2.2 \\
\hline Oxamniquine 400 & 23 & 13 & 12 & $28.9(51.1)^{a}$ & 0 & 0.3 & 4 & $27.7^{a}$ & 41.8 & $13^{a}$ & $13.3^{a}$ \\
\hline Artesunate 600 & 23 & 13 & 12 & $25.8(56.3)^{a}$ & 0 & 0.3 & 0.3 & $4.9^{a}$ & $32^{c}$ & $23.6^{a}$ & $38.8^{b}$ \\
\hline Praziquantel 800 & 23 & 13 & 13 & $40.5(31.6)^{a}$ & 0 & 0.6 & 1.4 & 10.5 & 61.2 & $25.8^{a}$ & 0.4 \\
\hline Control & - & - & 12 & $59.1(0)$ & 0 & 0.1 & 1.3 & 10.4 & 42 & 45.1 & 1 \\
\hline
\end{tabular}

$a$ : statistically significant difference in relation to control $(\mathrm{p} \leq 0.05) ; b$ : statistically significant difference of artesunate in relation to praziquantel and oxamniquine $(\mathrm{p} \leq 0.05) ; c$ : statistically significant difference of artesunate in relation to praziquantel $(\mathrm{p} \leq 0.05)$; NI: schistosomules with damaged intestines that did not allow their identification.

treated with $200 \mathrm{mg} / \mathrm{kg}$ or $400 \mathrm{mg} / \mathrm{kg}$ oxamniquine, or with $300 \mathrm{mg} / \mathrm{kg}$ or $600 \mathrm{mg} / \mathrm{kg}$ artesunate, 15 or 23 days after infection, showed a significant statistical reduction in the number of collected male and female worms. Treatment with praziquantel resulted in significant reduction only in the number of male worms, about $40 \%$ in reduction when doses of $400 \mathrm{mg} / \mathrm{kg}$ or $800 \mathrm{mg} / \mathrm{kg}$ were administered 23 or 15 days post-infection, respectively.

The percentage of immature worms collected reached a maximum of $2.4 \%$ in untreated mice of the control group. Treatment with $300 \mathrm{mg} / \mathrm{kg}$ artesunate, 15 days after infection or $600 \mathrm{mg} / \mathrm{kg} 23$ days after infection, significantly increased the percentage of immature worms $(15.4 \%$ and $40.4 \%$, respectively). Treatment with $200 \mathrm{mg} / \mathrm{kg}$ or 400 $\mathrm{mg} / \mathrm{kg}$ oxamniquine, 23 days post-infection, significantly increased the percentage of recovered immature worms (20.3\% and $34.9 \%$, respectively). When treatment with $400 \mathrm{mg} / \mathrm{kg}$ oxamniquine was administered 15 days after infection, there was a significant statistical increase of $16.8 \%$ in the percentage of immature worms (Table II).

In the experiments using praziquantel and artesunate in monotherapy or in association, it was observed a significant reduction in the mean number of worms collected by perfusion, except for the groups treated with 400 $\mathrm{mg} / \mathrm{kg}$ praziquantel, 14 or 21 days after infection. When treatments performed in monotherapy were compared with those ones using drugs in association, the results related to decrease in the average of worms were similar. Praziquantel used in monotherapy significantly reduced the percentage of fourth stage worms $(400 \mathrm{mg} / \mathrm{kg}$ and 800 $\mathrm{mg} / \mathrm{kg}$ administered 21 days after infection); artesunate in monotherapy was more effective reducing the number of worms (3rd and 4th stages), when used at the doses of $300 \mathrm{mg} / \mathrm{kg}$ or $600 \mathrm{mg} / \mathrm{kg}, 21$ days after infection. It was observed a significant increase in the number of young worms, which were not identified due to intestinal damages in animals treated with artesunate in monotherapy or with other drug in association, but not in treatment schedules with only praziquantel (Table III).

Mice treated with oxamniquine $(200 \mathrm{mg} / \mathrm{kg}$ or 400 $\mathrm{mg} / \mathrm{kg})$, artesunate $(300 \mathrm{mg} / \mathrm{kg}$ or $600 \mathrm{mg} / \mathrm{kg})$ or praziquantel (400 mg/kg or $800 \mathrm{mg} / \mathrm{kg}), 14$ or 21 days post-infection, and evaluated 100 days after infection, presented a significant reduction in the number of worms (37-74\%) in relation to the control group. No significant difference in reduction of the average of worms between the treated groups at different schedules could be observed. Worm distribution in mesentery and liver was similar to the control group and no dead worms were detected in the liver. Nevertheless, the oogram was altered in all the groups, except in those treated with praziquantel on days 14 post-infection (Table IV). 


\section{TABLE II}

Adult worm burden recovered from mice infected with 200 Schistosoma mansoni cercariae treated with single dose by oral route as monotherapy and submitted to euthanasia (treated and control groups) 42 days after treatment

\begin{tabular}{|c|c|c|c|c|c|c|c|}
\hline \multirow[b]{2}{*}{$\begin{array}{l}\text { Treatment schedule } \\
(\mathrm{mg} / \mathrm{kg})\end{array}$} & \multicolumn{4}{|c|}{$\begin{array}{l}\text { Animals } \\
\text { (n) }\end{array}$} & \multicolumn{3}{|c|}{$\begin{array}{c}\text { Worms } \\
\mathrm{n}(\% \text { reduction })\end{array}$} \\
\hline & $\begin{array}{l}\text { Ireated after } \\
\text { infection } \\
\text { (days) }\end{array}$ & Treated & Examined & $\begin{array}{l}\text { Mean of worm } \\
\text { (\% reduction) }\end{array}$ & Males & Females & $\begin{array}{l}\text { Immature } \\
\text { worms }\end{array}$ \\
\hline Oxamniquine 200 & 15 & 13 & 12 & $33.7(46.8)^{a}$ & $194(49.7)^{a}$ & $191(53.8)^{a}$ & $19(4.7)$ \\
\hline Artesunate 300 & 15 & 13 & 13 & $22.5(61.4)^{a}$ & $129(66.5)^{a}$ & $134(66.5)^{a}$ & $45(15.4)^{a}$ \\
\hline Praziquantel 400 & 15 & 13 & 12 & $41.2(34.9)^{a}$ & $244(36.8)^{a}$ & $223(37.2)$ & $39(7.7)$ \\
\hline Control & - & - & 13 & $58.4(0)$ & $386(0)$ & $355(0)$ & $18(0)$ \\
\hline Oxamniquine 200 & 23 & 12 & 12 & $52.4(25.7)$ & $228(39.6)^{a}$ & $273(39.3)^{a}$ & $128(20.3)^{a}$ \\
\hline Artesunate 300 & 23 & 12 & 11 & $43.7(43.2)^{a}$ & $200(47.5)^{a}$ & $248(44.9)^{a}$ & $33(6.9)$ \\
\hline Praziquantel 400 & 23 & 12 & 12 & $52.4(25.7)$ & $277(27.3)$ & $282(37.8)^{a}$ & $70(11.1)$ \\
\hline Control & - & - & 12 & $70.6(0)$ & $381(0)$ & $450(0)$ & $18(0)$ \\
\hline Oxamniquine 400 & 15 & 15 & 15 & $40.8(55.1)^{a}$ & $233(65.8)^{a}$ & $270(60.4)^{a}$ & $104(16.8)$ \\
\hline Artesunate 600 & 15 & 13 & 15 & $35.1(61.4)^{a}$ & $241(63.6)^{a}$ & $261(61.7)^{a}$ & $24(4.6)$ \\
\hline Praziquantel 800 & 15 & 15 & 15 & $53.8(40.9)^{a}$ & $339(48.8)^{a}$ & $362(46.9)^{a}$ & $52(6.9)$ \\
\hline Control & - & - & 14 & $97.5(0)$ & $662(0)$ & $682(0)$ & $21(0)$ \\
\hline Oxamniquine 400 & 23 & 14 & 13 & $20.9(75)^{a}$ & $64(88.9)^{a}$ & $113(77.3)^{a}$ & $95(34.9)^{a}$ \\
\hline Artesunate 600 & 23 & 14 & 14 & $327(57.9)^{a}$ & $141(76.6)^{a}$ & $132(73.4)^{a}$ & $185(40.4)^{a}$ \\
\hline Praziquantel 800 & 23 & 14 & 12 & $56.8(37.4)^{a}$ & $329(42.9)^{a}$ & $314(36.8)$ & $38(5.6)$ \\
\hline Control & - & - & 13 & $83.8(0)$ & $577(0)$ & $497(0)$ & $15(0)$ \\
\hline
\end{tabular}

$a$ : statistically significant difference in relation to control $(\mathrm{p} \leq 0.05)$.

TABLE III

Distribution of young worms recovered from mice infected with 200 Schistosoma mansoni cercariae treated with single dose by oral route as monotherapy and combination of drugs and submitted to euthanasia (treated and control groups) five days after treatment

\begin{tabular}{|c|c|c|c|c|c|c|c|c|c|c|c|}
\hline \multirow[b]{2}{*}{$\begin{array}{l}\text { Treatment schedule } \\
(\mathrm{mg} / \mathrm{kg})\end{array}$} & \multicolumn{4}{|c|}{$\begin{array}{l}\text { Animals } \\
\text { (n) }\end{array}$} & \multicolumn{7}{|c|}{$\begin{array}{c}\text { Distribution of schistosomules } \\
\text { per evolutive stage } \\
(\%)\end{array}$} \\
\hline & $\begin{array}{l}\text { infection } \\
\text { (days) }\end{array}$ & Treated & Examined & $\begin{array}{l}\text { Mean of worm } \\
(\% \text { reduction })\end{array}$ & 1 & 2 & 3 & 4 & 5 & 6 & NI \\
\hline Praziquantel 400 & 14 & 11 & 10 & $29.3(32.6)$ & 0.3 & 5 & 24 & 68 & 0.3 & 0 & 1.6 \\
\hline Praziquantel 800 & 14 & 11 & 11 & $23.5(46)^{a}$ & 0.4 & 4.7 & 31 & $54.3^{a}$ & 6.6 & 0 & 3.1 \\
\hline Artesunate 300 & 14 & 11 & 10 & $17.9(58.9)^{a}$ & 1.2 & 8.7 & $16.9^{a}$ & $53.5^{a}$ & 0.6 & 0 & $19.2^{a}$ \\
\hline Artesunate 600 & 14 & 11 & 9 & $7.7(82.3)^{a}$ & 1.4 & $20.3^{a}$ & $7.2^{a}$ & $34.8^{a}$ & 1.4 & 0 & $34.8^{a}$ \\
\hline Praziquantel $400+$ artesunate 300 & 14 & 12 & 12 & $9.8(77.5)^{a}$ & 2.5 & 16.9 & $29.7^{a}$ & $42.4^{a}$ & 0 & 0 & $8.5^{a}$ \\
\hline Praziquantel $800+$ artesunate 600 & 14 & 12 & 11 & $9.1(79.1)^{a}$ & 1 & 5.9 & 18.8 & $55.4^{a}$ & 1 & 0 & $17.8^{a}$ \\
\hline Control & - & - & 12 & $43.5(0)$ & 0.6 & 3.8 & 18.6 & 73.9 & 2.3 & 0 & 0.8 \\
\hline Praziquantel 400 & 21 & 11 & 10 & $57.6(5.6)$ & 0 & 1.7 & 3.8 & 34.9 & 44.4 & $13.7^{a}$ & 1.4 \\
\hline Praziquantel 800 & 21 & 11 & 11 & $36.0(41)^{a}$ & 0 & 0.3 & 9.6 & 34.1 & 45.4 & $9.6^{a}$ & 0.8 \\
\hline Artesunate 300 & 21 & 11 & 11 & $26.9(55.9)^{a}$ & 0 & 0.3 & 1.4 & 10.1 & 29.4 & $14.5^{a}$ & $44.3^{a}$ \\
\hline Artesunate 600 & 21 & 12 & 12 & $20.6(66.2)^{a}$ & 0 & 0.8 & 0 & 15.4 & 35.2 & $4.9^{a}$ & $43.7^{a}$ \\
\hline Praziquantel $400+$ artesunate 300 & 21 & 12 & 11 & $29.3(52)^{a}$ & 0 & 0.9 & 3.4 & 27 & 27.6 & $4.7^{a}$ & $36.6^{a}$ \\
\hline Praziquantel $800+$ artesunate 600 & 21 & 12 & 11 & $19.2(68.5)^{a}$ & 0 & 0.5 & 4.3 & 19.9 & 38.9 & $8.1^{a}$ & $28.4^{a}$ \\
\hline Control & - & - & 11 & $61(0)$ & 0 & 0.3 & 3.3 & 21.6 & 37.9 & 35.2 & 1.8 \\
\hline
\end{tabular}

$a$ : statistically significant difference in relation to control $(\mathrm{p} \leq 0.05)$; NI: schistosomules with damaged intestines that did not allow their identification. 


\section{TABLE IV}

Results obtained using mice experimentally infected with 50 Schistosoma mansoni cercariae treated by oral route single dose as monotherapy 14 or 21 days after infection and sacrificed 100 days after infection

\begin{tabular}{|c|c|c|c|c|c|c|c|c|}
\hline \multirow[b]{2}{*}{$\begin{array}{l}\text { Treatment schedule } \\
(\mathrm{mg} / \mathrm{kg})\end{array}$} & \multirow[b]{2}{*}{$\begin{array}{l}\text { Treated after } \\
\text { infection } \\
\text { (days) }\end{array}$} & \multicolumn{2}{|c|}{$\begin{array}{l}\text { Animals } \\
\text { (n) }\end{array}$} & \multicolumn{3}{|c|}{$\begin{array}{l}\text { Distribution of worms } \\
(\%)\end{array}$} & \multirow[b]{2}{*}{$\begin{array}{c}\text { Dead worms } \\
\text { in the liver } \\
(\%)\end{array}$} & \multirow[b]{2}{*}{$\begin{array}{c}\text { Oogram } \\
\text { changes } \\
(\%)\end{array}$} \\
\hline & & Treated & Examined & $\begin{array}{l}\text { Mean of worm } \\
\text { (\% reduction) }\end{array}$ & Mesentery & Liver & & \\
\hline Oxamniquine 200 & 14 & 15 & 11 & $7.1(65)^{a}$ & 86.2 & 13.8 & 0 & $45.5^{a}$ \\
\hline Artesunate 300 & 14 & 15 & 9 & $7.0(65.3)^{a}$ & 94.9 & 5.1 & 0 & 11.1 \\
\hline Praziquantel 400 & 14 & 15 & 13 & $12.6(37.6)$ & 97.6 & 2.4 & 0 & 0 \\
\hline Oxamniquine 200 & 21 & 15 & 11 & $7.4(63.6)^{a}$ & 93.6 & 6.4 & 0 & 27.3 \\
\hline Artesunate 300 & 21 & 15 & 13 & $5.2(74.3)^{a}$ & 95.6 & 4.4 & 0 & 16.4 \\
\hline Praziquantel 400 & 21 & 15 & 7 & $9.3(54)^{a}$ & 82.4 & 17.6 & 0 & 28.6 \\
\hline Control & - & - & 13 & $20.2(0)$ & 88.5 & 11.5 & 0 & 0 \\
\hline Oxamniquine 400 & 14 & 15 & 11 & $5.2(67.9)^{a}$ & 76.2 & 23.8 & 9.5 & $63.6^{a}$ \\
\hline Artesunate 600 & 14 & 15 & 13 & $4.5(72.2)^{a}$ & 81 & 19 & 0 & 15.4 \\
\hline Praziquantel 800 & 14 & 15 & 8 & $9.5(41.4)$ & 76.9 & 23.1 & 0 & 0 \\
\hline oxamniquine 400 & 21 & 15 & 12 & $6.8(58)^{a}$ & 85.2 & 14.8 & 0 & $58.6^{a}$ \\
\hline Artesunate 600 & 21 & 15 & 11 & $5.7(64.8)^{a}$ & 87.3 & 12.7 & 0 & 27.3 \\
\hline Praziquantel 800 & 21 & 15 & 7 & $7.9(51.2)^{a}$ & 83.6 & 16.4 & 0 & 14.3 \\
\hline Control & - & - & 15 & $16.2(0)$ & 86.1 & 13.9 & 0 & 0 \\
\hline
\end{tabular}

$a$ : statistically significant difference in relation to untreated control $(\mathrm{p} \leq 0.05)$.

It is important to emphasise that even performing perfusion 100 days after infection, a part of the recovered worms in treated groups $(400 \mathrm{mg} / \mathrm{kg}$ oxamniquine and $600 \mathrm{mg} / \mathrm{kg}$ artesunate) remained small and with fragile aspect. Most of the females were with a clearlooking intestine, seeming to be female immature worms. In the group treated with artesunate $(600 \mathrm{mg}$ / $\mathrm{kg}, 21$ days post-infection) 16 out of 34 (47.1\%) females presented immature characteristics, whereas 14 out of $36(38.9 \%)$ females seemed to be immature in the group treated 14 days after infection. In the group treated with oxamniquine (400 mg/kg, 21 days post-infection) 22 out of $49(44.9 \%)$ females showed an immature aspect, while eight out of $28(28.6 \%)$ females showed an immature aspect in the group treated 14 days after infection.

\section{DISCUSSION}

The asynchronous development of $S$. mansoni at the pre-patent phase was clearly observed in this study and the distribution of the immature worms recovered in the untreated control groups was similar to that reported by Barbosa et al. (1978).

These results here presented show that the drug interferes in the worm development, slowing or blocking the development of parasites, since significant percentages of worms with an immature aspect were detected up to 100 days after infection. This original finding has important implications in the fields of pathology, diagnosis and epidemiology of schistosomiasis.

Oogram alteration was observed in worms of the group treated with oxamniquine $(200 \mathrm{mg} / \mathrm{kg}$ or $400 \mathrm{mg}$ / $\mathrm{kg}), 14$ or 21 days after infection, and submitted to euthanasia 42 days post-infection, indicating that treatment interfered with sexual maturation of the worms, since immature females were recovered.

In the animals treated with $300 \mathrm{mg} / \mathrm{kg}$ or $600 \mathrm{mg} /$ $\mathrm{kg}$ artesunate, 14 or 21 days post-infection, a small percentage of oogram changes could be observed, although not statistically significant, is of relevance. According to Araújo et al. (1999), treatment with artesunate, at the postural phase, is capable of interrupting egg-laying only temporarily.

Praziquantel and derivatives of artesunate shown to be effective in different stages of worm development, being suggested that these drugs would be more efficacious when administered in association than in monotherapy (Inyang-Etoh et al. 2008, Abdul-Ghani et al. 2009). Promising results were obtained with praziquantel/artesunate in association, when administered in S. mansoni and Schistosoma japonicum infected mice, presenting immature and mature worms, simultaneously (Utzinger et al. 2001).

These data were not corroborated by De Clercq et al. (2000) in infected patients, in an endemic area for S. mansoni. In the present study, the results obtained with combination of $400 \mathrm{mg} / \mathrm{kg}$ praziquantel $+300 \mathrm{mg} / \mathrm{kg}$ artesunate, or $800 \mathrm{mg} / \mathrm{kg}$ praziquantel $+600 \mathrm{mg} / \mathrm{kg}$ artesunate, administered 14 or 21 days post-infection, did not show therapeutic advantages, since the profile presented by drug associations was similar to that observed when artesunate was administered alone. Perhaps, a better result can be obtained if the association is used in mixed infections, with adult and immature worms (Utzinger et al. 2001). 
The experimental chemotherapy at the pre-postural phase of $S$. mansoni is a field of great importance for development of antischistosomal drugs, due to its potential to eliminate the parasitism before lying of eggs, which cause the major injuries responsible for the disease - the granulomatous inflammatory reactions (Enk et al. 2008, Coelho et al. 2009). Thus, experimental chemotherapy is of the utmost importance and deserves a greater number of studies in this direction.

Worms treated at the early phase of infection (unfertile worms), 100 days post-chemotherapy, could maintain an immunological response, as well as the presence of circulating antigens in blood, even in absence of eggs in the faeces.

These findings represent a major cause of confusion regarding the interpretation of schistosomiasis mansoni diagnosis: the absence of eggs in the faeces, but maintenance of specific immune response, the presence of circulating antigens and genetic material of $S$. mansoni worms (detected by polymerase chain reaction techniques).

The results obtained allow us to conclude that the schistogram method used in this study proved to be a useful tool for experimental evaluation of the activity of antischistosomal drugs, at the early stages of infection, besides being a good model to investigate which of the evolutive stages are more sensitive to antischistosomal drugs.

\section{REFERENCES}

Abdul-Ghani R, Loutfy N, Sahn AE, Hassan A 2009. Current chemotherapy arsenal for schistosomiasis mansoni: alternatives and challenges. Parasitol Res 104: 955-965.

Araújo N, Kohn A, Katz N 1999. Therapeutical evaluation of the artesunate in experimental Schistosoma mansoni. Rev Soc Bras Med Trop 32: 7-12.

Barbosa MA, Pellegrino J, Coelho PMZ, Sampaio IBM 1978. Quantitative aspects of the migration and evolutive asynchronism of Schistosoma mansoni in mice. Rev Inst Med Trop S Paulo 20: 121-132.

Bogliolo L 1959. Schistosomiasis mansoni. Pathology. Rev Bras Malariol Doenças Trop 11: 359-424.

Botros S, Pica-Mattoccia L, William S, El-Lakkani N, Cioli D 2005. Effect of praziquantel on the immature stages of Schistosoma haematobium. Int J Parasitol 35: 1453-1457.

Coelho PMZ, Enk MJ, Katz N 2009. Treatment of clinical schistosomiasis at the prepatent phase: an option? Trends Parasitol 25: 299-300.

De Clercq D, Vercruysse J, Verlé P, Kongs A, Diop M 2000. What is the effect of combining artesunate and praziquantel in the treatment of Schistosoma mansoni infections? Trop Med Inter Health 5: 744-746.

Enk MJ, Katz N, Coelho PMZ 2008. A case of Schistosoma mansoni infection treated during the prepatent period. Natur Clin Prac Gastroenterol Hepato 15: 112-115.
Faust EC, Jones CA, Hoffman WA 1934. Studies on schistosomiasis mansoni in Puerto Rico. III - Biological studies. 2. The mammalian phase of the life cycle. Puerto Rico J Publ Healt Trop Med 10: 133-196.

Grandière-Pérez L, Ansart S, Paris L, Faussart A, Jaureguiberry S, Grivois JP, Klement E, Bricair F, Danis M, Caumes E 2006. Efficacy of praziquantel during the incubation and invasive phase of Schistosoma haematobium schistosomiasis on 18 travelers. Am J Trop Med Hyg 74: 814-818.

Inyang-Etoh PC, Ejezie GC, Useh MF, Inyang-Etoh EC 2008. Efficacy of a combination of praziquantel and artesunate in the treatment of urinary schistosomiasis in Nigeria. Trans $R$ Soc Trop Med Hyg 103: 38-44.

Lu SH, Yan XL, Li SW, Wu LJ, Shi JF, Liu X, Yan XH, Yang MJ, Lou LJ, Kumagai T, Wen LY, Ohta N 2004. Prophylactic effect of artesunate against experimental infection of Schistosoma mansoni. Chinese Journal of Parasitology \& Parasitic Diseases 22: 20-23.

Pellegrino J, Katz N 1968. Experimental chemotherapy of Schistosoma mansoni. Adv Parasitol 6: 233-291.

Pellegrino J, Siqueira AF 1956. Técnica de perfusão para colheita de Schistosoma mansoni em cobaias experimentalmente infectadas. Rev Bras Malariol Doencas Trop 8: 589-597.

Pellegrino J, Oliveira CA, Faria J, Cunha AS 1962. New approach to the screening of drugs in experimental schistosomiasis mansoni in mice. Amer J trop Med Hyg 11: 201-215.

Pica-Mattoccia L, Cioli D 2004. Sex and stage-related sensitivity of Schistosoma mansoni to in vivo and in vitro praziquantel treatment. Int J Parasitol 34: 527-533.

Sabah AA, Fletcher C, Webbe G, Doenhoff MJ 1986. Schistosoma mansoni: chemotherapy of infections of different ages. Exp Parasitol 61: 294-303.

Shaohong L, Kumagai T, Qinghua A, Xiaolan Y, Ohmae H, Yabu Y, Sewen L, Liyong W, Maruyama H, Ohta N 2006. Evaluation of the anthelmintic effects of artesunate against experimental Schistosoma mansoni infection in mice using different treatment protocols. Parasitol Int 55: 63-68.

Silva LM, Menezes RMC, Oliveira SA, Andrade ZA 2003. Chemotherapeutic effects on larval stages of Schistosoma mansoni during infection and re-infection of mice. Rev Soc Bras Med Trop 36: $335-341$.

Utzinger J, Chollet J, Tu Z, Xiao S, Tanner M 2002. Comparative study of the effects of artemether and artesunate on juvenile and adult Schistosoma mansoni in experimentally infected mice. Trans R Soc Trop Med Hyg 96: 318-323.

Utzinger J, Chollet J, You J, Mei J, Tanner M, Xiao S 2001. Effect of combined treatment with praziquantel and artesunate on Schistosoma japonicum and Schistosoma mansoni in experimentally infected animals. Acta Trop 80: 9-18.

Warren S 1968. Pathophysiology and pathogenesis of hepatosplenic schistosomiasis mansoni. Bull N Y Acad Med 44: 280-294.

Xiao SH, Catto BA, Webster Jr LT 1985. Effects of praziquantel on different developmental stages of Schistosoma mansoni in vitro and in vivo. $J$ Infect Dis 151: 1130-1137. 